\title{
Personal determinants of acceptance of drinking and driving among Polish drivers
}

\author{
Marcin Szulc ${ }^{A, B, D, E, F}$, Aleksandra Peplińska ${ }^{A, B, D, E, F}$, Piotr Połomski ${ }^{A, B, C, E}$, \\ Magdalena Wyszomirska-Góra ${ }^{A, B, F}$ \\ Institute of Psychology, University of Gdansk, Gdansk, Poland
}

\section{BACKGROUND}

The aim of the study was to explore a number of personal predictors that increase one's approval of driving under the influence (DUI). In keeping with the previous studies, we assumed this approval will more often be expressed by unmarried young men with a lower level of education, who are additionally characterized by a higher need for stimulation, risk acceptance, sensation seeking, and a preference for hedonic values.

\section{PARTICIPANTS AND PROCEDURE}

After examining more than 1000 drivers, we selected a group of 254 individuals (97 men, 157 women) who formed our study group. In our survey, these drivers admitted to driving while intoxicated in the past, but at the same time declared that small doses of alcohol did not limit their driving skills. We used a set of research tools in order to verify the assumptions. The following tools measured temperamental and personality variables: Formal Characteristics of Behavior-Temperament Inventory, Risk Acceptance Scale, Stimulating-Instrumental Risk Invento- ry, Scheler Value Scale, Rotter's Locus of Control Scale, and Zuckerman's Sensation Seeking Scale.

\section{RESULTS}

Driving under the influence of alcohol is most often approved of by unmarried men who have a higher level of education and are characterized by low levels of sensory sensitivity, low levels of emotional reactivity, an internal locus of control, a high need for risks, high sensation-seeking tendencies, and who prefer vital and aesthetic values.

\section{CONCLUSIONS}

It is well justified to examine personal predictors of various dangerous road behaviors, such as driving under the influence of intoxicating substances. These studies could aid both creating effective social prevention programs and conducting psychological screening tests.

\section{KEY WORDS}

attitudes; values; sensation seeking; drinking and driving (DUI)

Corresponding author - Aleksandra Peplińska, Ph.D., Institute of Psychology, University of Gdansk,

4 Bażyńskiego Str., 80-952 Gdansk, Poland, e-mail: a.peplinska@ug.edu.pl

AUthors' CONTRIBUtion - A: Study design · B: Data collection · C: Statistical analysis · D: Data interpretation .

E: Manuscript preparation · F: Literature search · G: Funds collection

to Cite this article - Szulc, M., Peplińska, A., Połomski, P., \& Wyszomirska-Góra, M. (2016). Personal determinants of acceptance of drinking and driving among Polish drivers. Current Issues in Personality Psychology, 4(2), 75-86.

RECEIVED 01.03.2016 · REVIEWED 24.03.2016 · ACCEPTED 06.04.2016 · PUBLISHED 18.04.2016 


\section{BACKGROUND}

Poland is ranked among those European Union (EU) countries where alcohol consumption is a serious problem. The interviews of 2012 that examined more than 4000 people aged 18 or over revealed that as many as $84 \%$ of the adult Polish population drink alcohol. However, the vast majority of men and almost all women had a subjective feeling that on no occasion did they drink too much of it (http://www.tnsglobal.pl/jakpijapolacy/pdf/raport.pdf). According to the State Agency for the Prevention of AlcoholRelated Problems (PARPA), the average amount of pure alcohol consumed per capita increased from 6.52 liters in 1993 to 9.40 liters in 2014 (http://www. parpa.pl/index.php/badania-i-informacje-statystyczne/statystyki).

The World Health Organization (WHO) study announced that in 2012 we drank even more than that: as much as 11.60 liters of pure alcohol per capita. With these amounts, we put ourselves at the forefront of the most heavily drinking nations - and so far the unrivaled leaders among them have been: Belarus (17.80 1), Lithuania (16.90 1), the Russian Federation (14.80 l), and the Czech Republic (14.00 l) (http://apps.who.int/gho/data/node.main-euro. A1041?lang=en\&showonly=GISAH).

Such widespread alcohol consumption, conditioned by customs and culture, generates numerous social pathologies (Chodkiewicz, 2014). Undoubtedly, one of them is driving a vehicle after drinking alcohol (or while intoxicated) - this is considered a serious social issue and one of the main risk factors of road accidents (Howat, Sleet, \& Smith, 1991). Alcohol significantly reduces a driver's psychomotor skills (Voas, Torres, Romano, \& Lacey, 2012), makes it harder to correctly assess a situation, and creates favorable conditions for overestimating one's capabilities and underestimating risks (Gusfield, 1985; Laurence, Snortum, \& Zimring, 1988; Sheehan, 1994; Zador, Krawchul, \& Voas, 2000; Blomberg, Peck, Moskowitz, Burns, \& Fiorentino, 2005; Lewis, Watson, \& Tay, 2007). The younger the driver, the greater the risk of DWI, because such persons are less experienced (Peck, Gebers, Voas, \& Romano, 2008) but have a higher need for thrills, are eager to seek sensations, and accept risks (Donmez, Boyle, \& Lee, 2010).

Polish police statistics indicate that in 2014 alone drunk drivers caused 2579 road accidents (which makes up $7.40 \%$ of their total number), and that led to 363 persons dying (11.30\%) and 2971 being wounded $(7.00 \%)$. The most numerous drunk driving offenders were passenger car drivers. They were the perpetrators of 1838 accidents in which 256 persons died and 2313 were injured. Drunk drivers were responsible for $6.40 \%$ of the overall number of accidents caused by drivers (Symon, 2015). But when we confront these facts with Polish drivers' declarative attitudes towards driving under the influence (DUI) (tracked by a SARTRE 4 research project - Social Attitudes to Road Traffic Risk in Europe; http://www.attitudes-roadsafety.eu/), we get a truly grotesque portrayal. These studies show that - despite widespread alcohol consumption - Polish driver feel they are, as road users, exceptionally responsible in this respect.

The inhabitants of the Scandinavian countries are very self-restrained in not driving under the influence, so it is especially telling to compare them against southern, eastern, and western countries. The drivers from southern countries (Cyprus, Greece, Italy, and Spain) were found to be 9 times more likely to drive over the legal alcohol limit when compared with Scandinavia. For drivers from western countries (Austria, Belgium, France, Germany, Ireland, and Netherlands) it was 4.90 times, and for drivers from eastern countries (the Czech Republic, Estonia, Hungary, Poland, Serbia, and Slovenia) it was 3.40 times (http://www.attitudes-roadsafety.eu/). However, the survey conducted in 2000 by Warsaw's Motor Transport Institution on drivers' drinking and driving behaviors already pointed to a significantly higher result, even though in those times alcohol consumption was only 7.12 liters per capita. The results obtained after examining 575 persons from 28 cities showed that entirely sober drivers made up $58.50 \%$ of the group, those who sometimes drove after drinking some nominal amount of alcohol represented $29.50 \%$, while those unconcerned by driving while intoxicated (DWI) made up $12.00 \%$ of the group (http://www. parpa.pl/index.php?option=com_content $\&$ task=view \&id=250\&Itemid=186).

The National Council for Road Safety estimates that as many as $35 \%$ of Poles have witnessed cases of other people's DUI. Most of them were "distant friends" (93\%), friends $(80 \%)$ and immediate family members (more that 50\%) (http://www.its.waw.pl/ Powstrzymaj_pijanego_kierowce,0,3562,1.html).

Even a small amount of alcohol may have serious consequences. The National Council on Alcoholism and Drug Dependence, Inc. (NCADD) estimates that about $32 \%$ of fatal car accidents involve either a drunk driver or an intoxicated pedestrian. Alcohol reduces one's cognitive performance, information processing efficiency, attention, and motor coordination. As a result, a driver may take rash, hasty decisions and attempt difficult road maneuvers (http:// www.ncadd.org/index.php/learn-about-alcohol/ drinking-and-driving). Regrettably, many drivers are not aware of the consequences of alcohol consumption, such as drowsiness experienced on the following day or even after consuming small amounts of alcohol that do not raise the BAC (blood alcohol concentration) above the legal limit in a given country (Radun, Summala, \& Radun, 2009). Although social awareness regarding the consequences of driving 
under the influence of alcohol (or drugs) has been increasing, still nearly 13000 people in the USA die every year due to alcohol-associated accidents. Collisions and road traffic accidents linked to alcohol generate a cost of over 100 billion dollars to American taxpayers. In Poland, the number of accidents caused by intoxicated drivers has fallen by $327(-15.10 \%)$, the number of casualties by $32(-11.10 \%)$, and the number of wounded by $478(-17.10 \%)$ when compared with the corresponding figures for 2013 (Symon, 2015).

\section{DETERMINANTS OF DRIVING VEHICLES UNDER THE INFLUENCE OF INTOXICATING SUBSTANCES}

According to Watling and Freeman (2011), there are a number of behavioral and perceptual factors that can influence one's decision to drive under the influence of intoxicating substances.

Studies conducted by Havâneanu and Havâneanu (2012) indicated that a link exists between flouting the road rules and one's temperamental and personality make-up. These authors stipulated that such a tendency is connected with seeing the road rules as irrational, disregarding the law, and experiencing low levels of risk. Other studies support this view by confirming significant influences of temperamental traits, such as reactivity and activity (Makarowski, Peplińska, \& Nowopolski, 2010; Odachowska, 2012; Dykas \& Terelak, 2014), as well as personality variables. What is specifically emphasized in this respect is the sensation-seeking tendency (Garrity \& Demick, 2001; Delhomme, Chaurand, \& Paron, 2012), risk acceptance (Peplińska, Połomski, WyszomirskaGóra, \& Szulc, 2015), and a preference for hedonic values (Wontorczyk, 2011). As it turns out, DUI is independent of any other risky road behaviors, such as not wearing a seatbelt or speeding (Shinar, Schechtman, \& Compton, 2001; Fernandes, Hatfield, \& Soames, 2010). Studies by Shinar et al. (2001) revealed that women more often claim to follow such rules as seatbelt use, observing speed limits, and not driving after alcohol, though Schwartz (2008), having analyzed various statistics from 1982-2004, noted that the number of female offenders of DUI went up, and the number of male offenders went down and then plateaued. Schwartz explains that women are more prone to be arrested and that more stringent laws and enforcement directed against less intoxicated offenders may inadvertently target female offending patterns.

Zuckerman (1994) suggested that the reason behind young (aged 16-20) men's risky driving is a tendency to seek sensations. This is understood as pursuing new, varied, complex and intense sensations and experiences, and at the same time it entails their readiness to take physical, social, legal, and finan- cial risks in order to provide themselves with these thrills (Beirness \& Simpson, 1988; Beirness, 1993; Jonah, Thiessen, \& Au-Yeung, 2001). Accepting risks is a characteristic feature of sensation seeking (Jonah, 1986). Individuals with a strong need to seek sensations will be more likely to speed, not to wear a seatbelt, and drive under the influence (Beirness \& Simpson, 1988; Jonah, 1997; Jonah et al., 2001; Peplińska et al., 2015).

Nolan, Johnson, and Pincus (1994) aimed to establish a specific personality type that characterizes drunk drivers. To do so, they examined 200 offenders of DWI. They used the Hogan Personality Inventory (HPI) and singled out 5 personality types: Impulsive-Extravert, Normal, Neurotic-Introvert, Neurotic-Hostile, and Unassertive-Conformist. These 5 categories group individuals of different demographic variables and drinking behaviors. Then, the authors compared results obtained by moderate drinkers, patients with diagnosed depression, inmates, and alcoholics. The Impulsive-Extravert and Normal types had similar HPI profiles to social drinkers. The Neurotic-Introvert type most resembled patients with depression; the Neurotic-Hostile type's profile most resembled inmates' personalities. The profile of DUI drivers was not found to be similar to that of alcoholics, but the authors suspect that in some cases DUI offenders may indeed have a drinking problem (Nolan et al., 1994).

Fernandes and Hatfield (2006) reported that when young people drive under the influence, it is connected with driver anger, road-unrelated illusory invulnerability, road-related specific illusory invulnerability, specific perceived susceptibility, perceived costs of drunk driving, and peer influence.

It seems that one's decision to drink and drive is also significantly influenced by individual attitudes towards social norms (Gulliver \& Begg, 2004) and by one's beliefs about drunk driving (Greenberg, Morral, \& Jain, 2005). Three hundred and eight Taiwan drivers were surveyed. The results indicated that a decision to drink and drive is taken, among others, when the society is customarily drinking alcohol, when drivers lack the full knowledge of the consequences of DUI, and when they do not think that getting caught by the police is very likely (Chang, Lin, Huang, \& Chang, 2013). Other researchers reported significant differences in attitudes towards DUI among sober and drunk drivers. Intoxicated individuals are more likely to accept DUI, less willing to consider any alternatives to DUI, they more often justify this behavior, and are more likely to believe that some people may actually become better drives after they have drunk alcohol. What is interesting, intoxicated drivers more than the sober ones realize what the negative consequences of DUI may be (Holubowycz \& McLean, 1995; Macdonald \& Dooley, 1993; Turrisi \& Jaccard, 1992). When Greening and 
Stoppelbein (2000) examined health-related attitudes on the basis of the Protection Motivation Theory (PMT), they found that young drivers are aware of the risks associated with DUI. The reason why they do it anyway is that this behavior is considered rewarding. What is more, respondents were more likely to drive under the influence if they had low self-efficacy and if choosing a different behavior was seen as incurring high personal costs.

Drinking alcohol may, but does not have to be, connected with social pathology. As mentioned earlier, the majority of Poles consume alcohol, but only 700 000-800 000 persons are addicted to it (Mellibru$\mathrm{da}, 2008$ ). The media, social campaigns and information given to learner drivers about the consequences of drunk driving may not significantly reduce the number of DUI offenders, but even so these are all factors that doubtlessly help build a greater awareness that it is dangerous to drive after alcohol. Thus we assume that this knowledge is shared by all drivers, and the problem lies in assimilating and applying it. In 2011, TNS OBOP (one of Poland's research agencies) asked Polish drivers with past DUI violations why they had decided to drink and drive. Most often the respondents said that it was necessary for them to drive or that they felt the amount of alcohol they had consumed was rather small. As this review of research studies suggests, whether drunk driving is accepted depends on a number of demographic, personality, and temperamental variables. The majority of key reports, including SARTRE 4 mentioned above, tend to overlook the importance of psychological variables, such as one's value system, sensation seeking, or temperament. This particular report only identifies demographic variables characteristic of drunk drivers from Eastern Countries (the Czech Republic, Estonia, Hungary, Poland, Serbia, and Slovenia). These drivers are most often males aged 25-54, low-educated, living alone or separated. They do not believe that drinking alcohol increases the accident risk. They also have the feeling of impunity (http:// www.attitudes-roadsafety.eu/).

\section{STUDY AIM}

Considering the research on determinants of DUI that we reviewed above, one cannot help but feel that studies which verify the significance of personality and temperamental factors in deciding to drink and drive are vastly insufficient. The aim of our study was to explore a number of personal predictors (both socio-demographic and psychological variables) that increase one's approval for driving while intoxicated. The results could help design better road safety programs, thus preventing road accidents. In keeping with the previous studies, we assumed this approval will more often be expressed by unmarried young men with a lower level of education, who are additionally characterized by a higher need for stimulation, risk acceptance, sensation seeking, and a preference for hedonic values.

\section{PARTICIPANTS AND PROCEDURE}

\section{PARTICIPANTS}

In keeping with these research assumptions, we used nonprobability sampling to select a group of drivers who felt liberal about DUI. Initially, a total of 1217 persons was surveyed. After examining a large population of drivers, we selected a group of 254 individuals (97 men, 157 women) who formed our study group. In our survey these drivers admitted to driving while intoxicated in the past (on more than one occasion), but at the same time declared that small doses of alcohol did not limit their driving skills. Their mean age was 28.70 years. The age range in this group was 19-46 years, and $29 \%$ of respondents had a stable relationship. $15.40 \%$ of drivers had children. $64 \%$ had a higher level of education. On average, the participants had had their driving licenses for 5 years.

Our strategy was to compose the examined group entirely of drivers who drove under the influence more than once (I sometimes drive after drinking alco$h o l)$. Some drivers may not remember how much they drank before they sat behind the wheel, while others may consciously underestimate or overestimate the amount of consumed alcohol. Therefore we decided that it would be a faulty approach to rely on survey data provided by the drivers themselves, instead of exact numbers of units of alcohol measured by the police with a breathalyzer. Moreover, to include in our examined group those individuals who did drink but felt well enough to drive would essentially mean including only their own subjective assessments of their driving abilities. It remains an indisputable fact that the greater the amount of consumed alcohol, the greater the accident risk (Blomberg et al., 2005). Nonetheless, we assumed that allowing oneself to drink and drive was enough to rank that driver as potentially dangerous, no matter how much alcohol he or she had consumed. The stance of the National Highway Traffic Safety Administration leaves no doubt in this regard: there is no such level of blood alcohol concentration that would not disrupt one's road behavior (http://www.ncadd.org/index.php/ learn-about-alcohol/drinking-and-driving).

\section{PROCEDURE}

The study was carried out between 2013 and 2014 . The participants were reached directly. Initially, we examined students, graduates, and employees of var- 
ious Tricity companies. Participant needed to have a driver's license and be willing to take part in the study. From this larger group we then isolated our examined group proper. For further examinations we selected the drivers who fulfilled the following criteria: they had a history of DUI violations, and they accepted driving after consuming small doses of alcohol. We recorded demographic variables such as sex, age, education level, and marital status.

\section{MEASURES}

We used a set of research tools in order to verify the assumptions. The following tools measured temperamental and personality variables:

- Temperament. Formal Characteristics of Behavior-Temperament Inventory (FCB-TI) created by Strelau (Strelau 2006; Zawadzki \& Strelau, 2010) and based on the Regulative Theory of Temperament (RTT), which is at present the most scientifically advanced theory used in screening drivers. The tool comprises 6 scales: briskness (a tendency to react quickly, maintain a high pace of one's actions, and to shift easily from one activity to the next), perseveration (a tendency to continue/repeat one's actions after the stimulus that originally triggered the behavior ceased to operate), sensory sensitivity (the ability to react to sensory stimuli of low stimulating value), emotional reactivity (a tendency to react intensively to emotion-generating stimuli - it is expressed as high emotional sensitivity and low emotional endurance), endurance (the ability to adequately react in situations which require prolonged or highly stimulating behaviors), and activity (a tendency to engage in behaviors of high stimulating value or behaviors that provide oneself with external stimulation). The reliability index measured with Cronbach's $\alpha$ was between .70 and .88 for particular subscales (Zawadzki \& Strelau, 2010).

- Risk acceptance. The Risk Acceptance Scale by Makarowski (2008) was developed in order to diagnose one's propensity for health-related risky behaviors. It was assumed that people with a high level of willingness to risk are also more prone to undertake unhealthy activities. The Risk Acceptance Scale can be used to estimate unhealthy risks through assessing one's unhealthy behaviors. The tool's reliability as measured with Cronbach's $\alpha$ is .81 .

- Risk taking. The Stimulating-Instrumental Risk Inventory (SIRI) by Makarowski (2007) was used to measure one's style of perceiving and interpreting risky behaviors. It distinguishes between two types of risk taking: stimulating risk taking (risk is seen as a way to provide oneself with stimulation, excitement and arousal; this kind of risk taking emphasizes activity, one's search for experiences realized through seeking highly stimulating situations, re- gardless of the outcome and risk of loss) and instrumental risk taking (here risk is perceived as an opportunity to achieve a positive outcome; taking risk occurs only when there is a chance of profit; this type of risk requires rational thinking and being focused on the goal). The tools' reliability measured with Cronbach's $\alpha$ ranges from .76 to .78.

- Values. In the SVS (Scheler Value Scale, D-50 version) adapted into Polish by Brzozowski (1995), 50 values are grouped into six basic scales - hedonic, vital, aesthetic, truth, moral, and sanctities; there are also four basic subscales: physical fitness and strength, endurance, secular sanctities, and religious sanctities. For the Polish version of the entire tool and its subscales, the reliability coefficient measured with Cronbach's $\alpha$ ranges from .81 to .89 . - Sensation. Zuckerman's Sensation Seeking Scale (SSS-V) adapted into Polish by Oleszkiewicz-Zsurzs (1985). The tool comprises 4 components: thrill and adventure seeking (TAS), experience seeking (ES), disinhibition (DIS), and boredom susceptibility (BS). The scale's internal reliability as measured with Cronbach's $\alpha$ ranges from .56 to .82 (Zuckerman, 1994).

- Locus of control. Rotter's Locus of Control Scale (1990) adapted into Polish by Karyłowski (1998). According to Rotter's theory, locus of control is a generalized dimension of personality, which accounts for an individual's tendency to perceive the causal connection between one's own actions and their consequences. Locus of control is a continuum ranging from a generalized feeling of internal control to a generalized feeling of external control. The lower one scores on the scale, the greater one's internal locus of control is. The split-half reliability was $r=.65$; reliability calculated with the Spearman-Brown prophecy formula $r=.79$; and Kuder-Richardson coefficients from three separate measurements were: $r=.69, r=.79, r=.70$.

\section{RESULTS}

We employed hierarchical linear regression using the "Enter" method in order to establish a set of causes which could explain the variability in whether drunk driving is accepted. The model assumes that there are three levels (sets) of factors which explain the dependent variable, i.e.: (set \#1) demographic variables (sex, age, education level, having children, the length of time one has had a driver's license, marital status) and personal variables, including: a) (set \#2) temperamental variables (briskness, perseveration, sensory sensitivity, emotional reactivity, endurance, and activity) analyzed also in the context of demographic variables, and finally b) (set \#3) personality variables (value system, tendency to engage in risky and stimulating activities, i.e. seeking sensations, experiences, and thrills; boredom susceptibility; self- 
Table 1

Model fit indices, including the statistic values for changes of model fits

\begin{tabular}{ccccccccc}
\hline $\begin{array}{c}\text { Model } \\
\text { (set no.) }\end{array}$ & $R^{2}$ & $\begin{array}{c}\text { Adjusted } \\
R^{2}\end{array}$ & SE & $R^{2}$ change & $\begin{array}{c}F \text { of } \\
\text { change }\end{array}$ & $d f 1$ & $d f 2$ & $\begin{array}{c}p \text { of } \\
\text { change }\end{array}$ \\
\hline 1 & .34 & .33 & 0.30 & .34 & 64.37 & 3 & 379 & .011 \\
2 & .52 & .52 & 0.25 & .18 & 72.54 & 2 & 377 & .012 \\
3 & .62 & .60 & 0.23 & .09 & 12.94 & 7 & 370 & .014 \\
\hline
\end{tabular}

Note. $R^{2}$ - squared multiple correlation; SE - standard error of revised $R^{2} ; F$ - F-test of significance of $R^{2} ; d f$ - degrees of freedom; $p$ - level of significance.

Table 2

Regression coefficients for the variables included in the hierarchical regression

\begin{tabular}{lccccc}
\hline Predictor & $B$ & SE & $\beta$ & $t$ & $p$ \\
\hline Sex (male) & .17 & .03 & .21 & 5.45 & .012 \\
Marital status & -.10 & .03 & -.13 & -3.86 & .001 \\
Education & .05 & .02 & .07 & 2.02 & .042 \\
Sensory sensitivity & -.02 & .003 & -.27 & -6.98 & .001 \\
Emotional reactivity & -.01 & .003 & -.09 & -2.10 & .043 \\
Sensation seeking & .01 & .003 & .15 & 3.75 & .012 \\
Locus of control & -.01 & .003 & -.07 & -1.20 & .041 \\
Aesthetic values & .002 & .001 & .11 & 2.56 & .021 \\
Vital values & .003 & .001 & .20 & 4.75 & .021 \\
Moral values & -.002 & .001 & -.15 & -3.57 & .011 \\
Stimulating risk & .01 & .002 & .13 & 3.42 & .002 \\
Instrumental risk & .01 & .003 & .11 & 2.98 & .014 \\
\hline
\end{tabular}

Note. $B$ - unstandardized regression weight; SE - standard error of unstandardized regression weight; $\beta$ - standardized regression weight; $t$ - $t$-test for significance of coefficient; $p$ - level of significance

esteem; locus of control; risk-taking tendencies; and risk acceptance) whose influence was analyzed in the context of demographic and temperamental factors.

The results we obtained (shown in Table 1) revealed that demographic variables (set \#1) explain more than $33 \%$ (adjusted $R^{2}=.33$ ) of variance of the dependent variable. In addition, temperamental variables (set \#2) improve predictability of accepting drunk driving by about $18 \%\left(R^{2}\right.$ change $\left.=.18\right)$, and this increase is significant: $F(2,377)=72.54, p=.012$. Next, personality variables (set \#3) analyzed in the context of demographic and temperamental factors further improve predictability by $9 \%\left(R^{2}\right.$ change $\left.=.09\right)$, which is also significant: $F(7,370)=12.94, p=.011$. From the data we gathered it follows that the hierarchical model of why DUI is accepted - taking demographic and personal variables (temperamental and personality ones) into account - predicts more than $60 \%\left(R^{2}=.60\right)$ of variance of the explained variable.

A detailed analysis (Table 2) shows that among demographic variables included in the model the fol- lowing are significant: $\operatorname{sex}(\beta=.21, p=.012)$, marital status $(\beta=-.13, p<.001)$, and education level $(\beta=.07$, $p=.042)-$ the male sex and education level correlate positively with accepting drunk driving, and marital status (being married) correlates negatively. The other demographic variables - age, having children, how long one has had a driver's license - did not influence the dependent variable significantly, so they were removed from the model. The data we gathered revealed that drinking and driving is most likely accepted by men who are single or cohabit, and who have a higher level of education. The significant temperamental variables include sensory sensitivity $(\beta=-.27, p<.001)$ and emotional reactivity $(\beta=-.09, p=.043)$ - both correlate negatively with the explained variable. Therefore, low levels of sensitivity and emotional reactivity (a need for experiencing greater stimulation in one's daily life) are statistically significant factors that contribute to accepting drinking and driving. Briskness, perseverance, endurance, and activity were all excluded from the model, since they were not significant in 
affecting variation of the dependent variable. Among the personality variables we examined, pursuing vital values (positive correlation: $\beta=.20, p=.021$ ) coupled with disregarding moral values (a negative correlation: $\beta=-.15, p=.011)$ turned out to be most strongly associated with accepting DUI. What also proved significant was seeking sensations and experiences (positive correlation: $\beta=.15, p=.012$ ), and a tendency to engage in risky behaviors of both stimulating $(\beta=.13$, $p=.002)$ and instrumental character $(\beta=-.11, p=.014)$. Drunk driving is also more likely to be accepted by individuals with an internal locus of control (negative correlation: $\beta=-.07, p=.041$ ). Having analyzed the three sets of predictors in the group of examined drivers, we claim that accepting DUI occurs more often when drivers feel they have control over their own future, and their philosophy of life is one of pursuing pleasures and strong emotions, even if it entails transgressing commonly accepted moral rules.

\section{DISCUSSION}

Based on the results of the performed analyses, we can explicitly confirm that there are some personal determinants of accepting DUI. The findings suggest that those who drive after drinking alcohol have a specific profile. As was hypothesized, drunk driving is more often approved of by unmarried men. This fact, as already mentioned above and covered in the literature on the subject, can be linked to the men's greater tendency to take risks (Peplińska et al., 2015) or seek sensations (Beirness \& Simpson, 1988; Beirness, 1993; Jonah et al., 2001). This interpretation is supported by the results which male drivers obtained when we tested their personality variables. Seccombe and IshiiKuntz (1994), however, put forward an entirely different, more prosaic explanation. Single men spend three times as many evenings with their friends as married men - this means more occasions to consume alcohol. An interesting result, although it is not in keeping with our initial hypothesis, is the one concerning education levels. The analyses showed that men are more likely to approve of DUI if their education level is higher - though these persons would normally be expected to be more self-aware and socially mature. Perhaps, then, this fact is not connected with one's maturity, but rather with a lifestyle adopted by this group of men, with their social status that predisposes them to defy social norms and rules. Studies by Sosnowski and Wiech (2006) found a negative correlation between one's education level and authoritarian personality. Better-educated individuals are less willing to respect norms rigidly and unquestioningly; for authoritarian personalities, on the other hand, this is the way to provide themselves with clear points of reference which tell them how to act.
When we consider temperamental and personality variables, the following were additional predictors of accepting DUI: low levels of sensory sensitivity, low levels of emotional reactivity, internal locus of control, high levels of sensation seeking, a need for taking risks - combined with pursuing vital and aesthetic values, while disregarding moral values. Miklewska and Miklewska (2000) demonstrated that low-level sensory sensitivity is typical of individuals at risk of alcohol addiction, which means individuals who are more prone to alcohol consumption (Grzegorzewska, 2013). Low-reactive persons, when compared with high-reactive ones, express a greater need for stimulation - this is due to their high activation level (Wytkowska, 2003). This result is consistent with the findings that DWI offenders have a high level of the sensation-seeking trait and report a high need for risk-taking. Kolańczyk (1991) noted that intuitive information processing is highly stimulating. It involves tolerating and not resolving ambiguity, having vague evaluation criteria, and not employing control processes.

Steptoe, Gardner, and Wardle (2010) argue that driving safely (wearing a seatbelt, observing the speed limit, driving only when one feels well enough) is one of five health-related behaviors. It would seem that an internal locus of control supports these very behaviors - driving safely and cautiously. Norman, Bennett, Smith, and Murphy (1998), however, showed that one's locus of control is of rather poor predictive value as far as health-related behaviors are concerned. If anything, it may act as a regulating factor for health-promoting activities among women with a drinking problem (Lipowski, Szulc, \& Buliński, 2015). It appears counter-intuitive, but has also been shown in some studies on people's awareness of harmful consequences of substance use (Bennett, Norman, Murphy, Moore, \& Tudor-Smith, 1998). Individuals who have the knowledge of how harmful smoking, alcohol abuse and drug-taking can be ignore obvious dangers and do not use this knowledge to protect their health - quite the contrary (Baran-Furga \& Steinbarth-Chmielewska, 2010). We suppose that an analogous mechanism is at work in the case of drivers we examined - risky behaviors, such as DUI, are disregarded or ignored.

All the variables described above are significant predictors of one's risky road behavior, as has already been shown many times in other studies (Garrity \& Demick, 2001; Dahlen \& White, 2006; Dykas \& Terelak, 2014). These dimensions of personality and temperament promote taking risks, engaging in risky situations while on the road, and pursuing extra stimulation, for example by speeding, aggressive driving (Farnicka \& Grzegorzewska, 2015), or driving under the influence of intoxicating substances (Gulliver \& Begg, 2004).

To understand the obtained results, we can also explain them with cultural issues in mind. Poland is 
often described as a new democracy. Over the past 25 years of freedom, a market economy has risen and grown. Consequently, people were forced to be more productive. In a market society people constantly compete against one another, and personal success is a commonly accepted measure of how one fares in this competition. But a fledgling democracy can also spawn certain pathologies. Access to promotion opportunities or social privileges is unequal, fierce competition is promoted despite the fact that it is driven by simplified, minimal effects - under these circumstances the winners are those who fit the rat race model well. They can easily adapt to situations where determination, need for achievement, and need for stimulation are required - and where lack of remorse is considered an advantage. Individuals who manage to succeed are those who identified the rules that govern a dynamically expanding society. Their success, among other things, is measured with their financial status. We did not collect information on whether the members of the examined group felt successful. Nor did we check whether disregarding the norms (DUI is an example of this) made them feel successful in these risky conditions. The model, however, seems to positively answer both questions. Driving under the influence offenders are typically single men with a high need for stimulation. They enjoy risks and seek them actively; they are rather well-educated, vigorous, they pursue vital values, but regard art and culture (aesthetic values) as social status symbols rather than the contents of their spiritual lives. Drivers who accept DUI are characterized by a sense of time pressure, need for achievements, efficacy, need for stimulation, and trying to confirm their traditionally masculine identity. Once they have adopted this attitude, favored by their temperamental make-up, they later approve of drunk driving. When Arnett (1990) studied egocentrism among young drivers, he found that those who tend to DUI (compared with those who do not) are much less inclined to believe they will cause an accident or be arrested for drunk driving. Aberg (1993), referring to Fishbein and Ajzen's model, confirmed that attitudes are of fundamental importance for DUI. Our examinations appear to support the view that accepting drunk driving is only one facet of a more complex issue - the dangerous driver syndrome.

\section{CONCLUSIONS}

In this study we established a set of variables that promotes accepting DUI. We explained them in the light of previous findings, as well as of cultural changes a new democracy undergoes. Achievement pressure, a chance to obtain measurable results thanks to their efforts - these traits may make certain drivers ignore the risk and accept DUI. Another issue we identified is the need to create a prevention system that reflects the diversity of variables that may affect one's decision to drink and drive. Therefore, considering the major roles of human factors in road traumas, it seems justified to focus preventive actions on changing the attitudes and beliefs among drivers in order to promote a healthier, safer lifestyle (Lewis et al., 2007). Studies show that legal measures taken to decrease the risk of DUI offenders driving drunk again have mixed effectiveness. An analysis revealed that legal sanctions are indeed perceived as quite severe, but not necessarily swift and inevitable. Moreover, one's past case of DUI and the amount of alcohol consumed were prognostic factors for driving while intoxicated. Some DUI recidivists do not respond to the threat of legal sanctions or even to their actual application. This means that various influences should be used to affect the population of drunk drivers and DUI recidivists (Freeman et al., 2006; Chang et al., 2013). On the basis of their own study, Schechtman, Shinar, and Compton (1999) concluded that social and information campaigns are only moderately effective, because - irrespective of prevention measures - those who drink more are simply more at risk of drunk driving again in the future. It seems that campaigns should encourage alternative behaviors instead of merely demonstrating negative consequences of DUI (Greening \& Stoppelbein, 2000). Campaigns should also emphasize that one's social environment can play a key role in discouraging a driver from driving after alcohol. The researchers argue that the risk of drunk driving can be significantly reduced if determined actions of a driver's friends are presented (Haglund \& Åberg, 2001; Fernandes \& Hatfield, 2006). In some cases, a combination of police actions, tougher penalties and lowering the breath alcohol concentration limits brought a significant decrease in the number of drunk drivers (Freeman et al., 2006; Campos et al., 2013). But why do drivers decide to drink and drive even though the possible consequences of this behavior (accidents, collisions, having one's driver's license revoked, etc.) are widely known? This question still remains to be answered. The results we obtained in our study are consistent and show quite clearly that drivers who approve of DUI have a distinct profile.

\section{LIMITATIONS}

Our examinations, however, are not without shortcomings. One limitation of the interpretation of results is that what we examined were drivers' attitudes towards DUI, and not attitudes of those who were actually caught drunk driving. The data are therefore declarative and may not be identical to the attitudes of actual DUI convicts. The respondents were asked if they had had their driver's license revoked or if 
they ever drove under the influence, and although the survey was entirely anonymous, some might have chosen not to admit to any of this. It would be beneficial to continue these studies if we had a chance to compare the results with those obtained by drivers who had their driver's license revoked as a result of DUI. Another limitation is the sample size and the group representativeness. Having recruited our participants from among students, graduates, and employees in large organizations, we effectively excluded individuals with lower education levels. Consequently, our conclusions concerning the education variable should be verified again. The way we reached the respondents ensured that the majority of the group was female, and this could later affect the results concerning socio-demographic variables. It would be justified to repeat the study, this time examining a more representative group - one that includes more individuals with lower education levels, more male respondents, and drivers whose license has been revoked as a result of DUI.

\section{IMPLICATIONS}

The conducted survey and the results we obtained tend to highlight two ranges of implications: at empirical and practical levels. It appears that it would be beneficial to continue the research in the discussed areas, this time including new groups in the study, i.e. those whose licenses have been revoked as a result of DUI, and those who are professional drivers. This would allow us to carry out a comparative analysis between these two groups. Additionally, we could examine the relationships between attitudes and behaviors connected with DUI. As already mentioned, the study would benefit from increasing the representativeness of the study group, not only in terms of one's educational status but also in terms of where the drivers are from. This matters because, as revealed by the TNS OBOP 2011 study, social consent to DUI is considerably greater in small towns than it is in large cities. Our findings can also provide a basis for practical actions. Let us point to social campaigns as the first area of practical applications. These campaigns aim to discourage drivers from DUI. The more we know about personal determinants of accepting DUI, the more effective the campaigns could be, as they would target precisely the group that needs to be educated. On the other hand, the results of this study could be of use in the area of psychological assessment - the possibilities of reclaiming one's driving license (or obtaining it in the first place) could be limited in the case of individuals whose psychological profiles indicate they may be potentially dangerous on the road. Finally, there is the important aspect of educating prospective drivers. As shown by the results, attitudes can significantly translate into specific actions taken on the road. Therefore, it seems well founded to increase the emphasis on shaping proper attitudes already at the stage of driver education and training.

\section{RefERENCES}

Arnett, J. (1990). Drunk driving, sensation seeking, and egocentrism among adolescents. Personality \& Individual Differences, 11, 541-546.

Aberg, L. (1993). Drinking and driving: intentions, attitudes, and social norms of Swedish male drivers. Accident Analysis and Prevention, 25, 289-296.

Baran-Furga, H., \&Steinbarth-Chmielewska,K.(2010). Zespoły uzależnień od substancji psychoaktywnych [Psychoactive substances dependence syndromes]. In P. Jabłoński \& J. C. Czabała (eds.), Uzależnienie od narkotyków. Podręcznik dla terapeutów [Drug addiction. A therapist's manual] (pp. 51-72). Krajowe Biuro do Spraw Przeciwdziatania Narkomanii.

Beirness, D. J. (1993). Do we really drive as we live? The role of personality factors in road crashes. Alcohol, Drugs and Driving, 9, 129-143.

Beirness, D. J., \& Simpson, H. M. (1988). Lifestyle correlates of risky driving and accident involvement among youth. Alcohol, Drugs and Driving, 4, 193-204.

Bennett, P., Norman, P., Murphy, S., Moore, L., \& Tudor-Smith, C. (1998). Beliefs about alcohol, health locus of control, value for health and reported consumption in a representative population sample. Health Education Research - Theory \& Practice, 13, 25-32.

Blomberg, R. D., Peck, R. C., Moskowitz, H., Burns, M., \& Fiorentino, D. (2005). Crash risk of alcohol involved driving: A case-control study. Stanford, CT: Dunlap \& Associates, Inc.

Brzozowski, P. (1995). Skala Wartości Schelerowskich - SWS [The Scheler Value Scale - SVS]. Warszawa: Pracownia Testów Psychologicznych PTP.

Chang, L., Lin, D., Huang, C., \& Chang K. (2013). Analysis of contributory factors for driving under the influence of alcohol: A stated choice approach. Transportation Research Part F: Traffic Psychology and Behaviour, 18, 11-20.

Chodkiewicz, J. (2014). Determinants of personality in the scope of motivation for maintaining abstinence in the case of male alcohol-dependent individuals concluding therapy. Current Issues in Personality Psychology, 2, 217-227.

Campos, V. R., de Souza e Silva, R., Duailibi, S., dos Santos, J. F., Laranjeira, R., \& Pinsky, I. (2013). The effect of the new traffic law on drinking and driving in Sao Paulo, Brazil. Accident Analysis and Prevention, 50, 622-627.

Dahlen, E. R., \& White, R. P. (2006). The Big Five factors, sensation seeking, and driving anger in the 
prediction of unsafe driving. Personality and Individual Differences, 41, 903-915.

Delhomme, P., Chaurand, N., \& Paran, F. (2012). Personality predictors of speeding in young drivers: Anger vs. sensation seeking. Transportation $R e-$ search Part F: Traffic Psychology and Behaviour, 15, 654-666.

Donmez, B., Boyle, L., \& Lee, J. (2010). Differences in off-road glances: effects on young drivers' performance. Journal of Transportation Engineering, 136, 403-409.

Dykas, J., \& Terelak, J. F. (2014). Temperamental traits and styles of coping stress in motorcyclists. The Polish Journal of Aviation Medicine and Psychology, 20, 11-18.

Farnicka, M. A., \& Grzegorzewska, I. (2015). Intrapersonal correlates of aggression in adolescents: determinants of adopting the role of the perpetrator and the victim. Current Issues in Personality Psychology, 3, 25-35.

Fernandes, R., \& Hatfield, J. (2006). Examination of different predictors of different risky driving behaviours in young NSW drivers. Final Report for the Motor Accidents Authority of NSW. NSW Injury Risk Management Research Centre University of NSW, Building G2, Western Campus Drive, Western Campus, Sydney 2052 NSW, Australia.

Fernandes, R., Hatfield, J., \& Soames, J. R. F. (2010). A systematic investigation of the differential predictors for speeding, drink-driving, driving while fatigued, and not wearing a seat belt, among young drivers. Transportation Research Part F: Traffic Psychology and Behaviour, 13, 179-196.

Freeman, J., Liossis, P., Schonfeld, C., Sheehan, M., Siskind, V., \& Watson, B. (2006) The self-reported impact of legal and non-legal sanctions on a group of recidivist drink drivers. Transportation Research Part F: Traffic Psychology and Behaviour, 9, 53-64.

Garrity, R., \& Demick, J. (2001). Relations among personality traits, mood states, and driving behaviors. Journal of Adult Development, 8, 109-118.

Greenberg, M. D., Morral, A. R., \& Jain, A. K. (2005). Drinking-driving and DUI recidivists' attitudes and beliefs: A longitudinal analysis. Journal of Studies on Alcohol, 66, 640-647.

Greening, L., \& Stoppelbein, L. (2000). Young drivers' health attitudes and intentions to drink and drive. Journal of Adolescent Health, 27, 94-101.

Grzegorzewska, I. (2013). Individual predispositions and positive adaptation of children of alcoholics. Current Issues in Personality Psychology, 1, 11-25.

Gulliver, P., \& Begg, D. (2004). Influences during adolescence on perceptions and behaviour related to alcohol use and unsafe driving as young adults. Accident Analysis and Prevention, 36, 773-781.

Gusfield, J. (1985). Social and cultural contexts of the drinking event. Journal of Studies in Alcohol, Suppl 10, 70-77.
Haglund, M., \& Åberg, L. Young people, drinking habits, transportation and peer relations. A questionnaire study. $14^{\text {th }}$ ICTCT workshop. Retrieved 15 April 2011 from www.ictct.org/dlObject.php?document_nr=236\&/Aberg.pdf; 2001.

Havâneanu, G. M., \& Havâneanu, C. E. (2012). When norms turn perverse: Contextual irrationality vs. rational traffic violations. Transportation Research Part F: Traffic Psychology and Behaviour, 15, 144-151.

Holubowycz, O., \& McLean, J. (1995). Demographic characteristics, drinking patterns and drink driving behaviour of injured male drivers and motorcycle riders. Journal of Studies on Alcohol, 56, 513-521.

Howat, P., Sleet, D., \& Smith, I. (1991). Alcohol and driving: is the $0.05 \%$ blood alcohol concentration limit justified? Drug and Alcohol Review, 10, 151-166.

Jonah, B. A. (1986). Accident risk and risk-taking behaviour among young drivers. Accident Analysis and Prevention, 18, 255-271.

Jonah, B. A. (1997). Sensation seeking and risky driving: A review and synthesis of the literature. Accident Analysis \& Prevention, 29, 651-665.

Jonah, B. A., Thiessen, R., \& Au-Yeung, E. (2001). Sensation seeking, risky driving and behavioral adaptation. Accident Analysis \& Prevention, 33, 679-684.

Kolańczyk, A. (1991). Intuicyjność procesów przetwarzania informacji [Intuitive aspects of information-processing functions]. Gdańsk: Wydawnictwo Uniwersytetu Gdańskiego.

Laurence, M., Snortum, J., \& Zimring, F. (eds.) (1988). Social Control of the Drinking Driver. Chicago: The University of Chicago Press.

Lewis, I., Watson, B., \& Tay, R. (2007). Examining the effectiveness of physical threats in road safety advertising: The role of the third-person effect, gender, and age. Transportation Research Part F: Traffic Psychology and Behaviour, 10, 48-60.

Lipowski, M., Szulc, M., \& Buliński, L. (2015). Physical activity among other health-related behaviors in treatment of alcoholism. The Journal of Sports Medicine and Physical Fitness, 55, 1-2.

Lucchetti, G., Koenig, H. G., Pinsky, I., Laranjeira, R., \& Vallada H. (2014). Religious beliefs and alcohol control policies: a Brazilian nationwide study. $R e^{-}$ vista Brasileira de Psiquiatria, 36, 4-10.

Macdonald, S., \& Dooley, S. (1993). A case-control study of driving-while-impaired offenders. Drug and Alcohol Dependence, 33, 61-71.

Majchrowska, A. (2000). Zdrowie jako wartość [Health as a value]. In I. Taranowicz, A. Majchrowska, \& Z. Kawczyńska-Butrym (eds.), Elementy socjologii dla pielęgniarek [Basic sociology for nurses] (pp. 123-141). Lublin: Czelej.

Makarowski, R. (2007). Jakie emocje występują podczas pierwszego w życiu lotu szybowcem oraz pierwszego w życiu skoku ze spadochronem? 
[What sort of emotions do we experience during our first glider flight and our first parachute jump?]. Medycyna Sportowa, 5, 279-284.

Makarowski, R. (2008). Granice ryzyka. Paradygmat psychologiczny [Risk limits. A psychological paradigm]. Cracow: Oficyna Wydawnicza Impuls.

Makarowski, R., Peplinska, A., \& Nowopolski, M. (2010). Psychological aspects of risk and aggression among motorcyclist - "Mad Max" syndrome. Polish Psychological Bulletin, 41, 74-83.

Mellibruda, J. (2008). Psychologiczna problematyka uzależnień od alkoholu i narkotyków. Psychopatologia zjawisk społecznych [Psychological aspects of alcohol and drug dependence. Psychopathology of social phenomena]. In J. Strelau (ed.), Psychologia (tom 3) [Psychology (Vol. 3)] (pp. 691-710). Gdańsk: GWP.

Miklewska, A., \& Miklewska, A. (2000). Związek temperamentu z zachowaniami agresywnymi i zagrożeniem uzależnieniem od alkoholu w świetle regulacyjnej teorii temperamentu J. Strelaua: Sprawozdanie z badań [Temperament vis-a-vis aggressive behavior and alcohol abuse in the light of J. Strelau's Regulative Theory of Temperament. A research report]. Przegląd Psychologiczny, 43, 173-190.

Nolan, Y., Johnson, J. A., \& Pincus, A. L. (1994). Personality and Drunk Driving: Identification of DUI Types Using the Hogan Personality Inventory. Psychological Assessment, 6, 33-40.

Norman, P., Bennett, P., Smith, C., \& Murphy, S. (1998). Health locus of control and health behaviour. Journal of Health Psychology, 3, 171-180.

Odachowska, E. (2012). Temperament a skłonność do zachowań ryzykownych w ruchu drogowym [Temperamental conditioning of hazardous behawior based on the analysis of drivers]. Transport Samochodowy, 1, 35-51.

Oleszkiewicz-Zsurz, Z. (1985). Adaptacja skali poszukiwania wrażeń (SSS) M. Zuckermana do warunków polskich [Adaptation of Zuckerman's Sensation-Seeking Scale (SSS) to Polish conditions]. Przeglad Psychologiczny, 28, 1123-1128.

Peck, R., Gebers, M. A., Voas, R. B., \& Romano, E. (2008). The relationship between blood alcohol concentration (BAC), age, and crash risk. Journal of Safety Research, 39, 311-319.

Peplińska, A., Wyszomirska-Góra, M., Połomski, P., \& Szulc, M. (2015). Who is a dangerous driver? Socio-demographic and personal determinants of risky traffic behavior. Current Issues in Personality Psychology, 3, 149-158.

Radun, I., Summala, H., \& Radun, J. E. (2009). Drinking and driving "safely": Who uses a breathalyzer and when? Transportation Research Part F: Traffic Psychology and Behaviour, 12, 155-158.

Seccombe, K., \& Ishii-Kuntz, M. (1994). Gender and social relationships among the never-married. Sex Roles, 30, 585-603.
Sheehan, M. (1994). Alcohol Controls and Drink Driving: the Social Context. Federal Office of Road Safety Monograph CR 142. Canberra: AGPS.

Schechtman, E., Shinar, D., \& Compton, R. C. (1999). The relationship between drinking habits and safe driving behaviors. Transportation Research Part F: Traffic Psychology and Behaviour, 2, 15-26.

Shinar, D., Schechtman, E., \& Compton, R. (2001). Self-reports of safe driving behaviors in relationship to sex, age, education and income in the US adult driving population. Accident Analysis and Prevention, 33, 111-116.

Schwartz, J. (2008). Gender differences in drunk driving prevalence rates and trends: A 20-year assessment using multiple sources of evidence. Addictive Behaviors, 33, 1217-1222.

Sosnowski, T., \& Wiech, M. (2006) Przesądność i próba jej pomiaru: Kwestionariusz Orientacji Przekonań (KOP20) [Superstition and its measurement: Development of the Questionnaire of Belief Openness]. Roczniki Psychologiczne, 11, 181-204.

Steptoe, A., Gardner, B., \& Wardle, J. (2010). The role of behaviour in health. In D. French, A. Kaptein, K. Vedhara, \& J. Weinman (eds.), Health Psychology (pp. 12-32). Oxford: Blackwell.

Strelau, J. (2006). Temperament jako regulator zachowania. Z perspektywy pótwiecza badań [Temperament as a regulator of behavior: After fifty years of research]. Warszawa: GWP.

Symon, E. (2015). Wypadki drogowe w Polsce w 2014 roku [Road accidents in Poland (2014)]. Wydział Ruchu Drogowego Biura Prewencji i Ruchu Drogowego Komendy Głównej Policji. http://statystyka.policja.pl/st/ruch-drogowy/76562,Wypadkidrogowe-raporty-roczne.html

Turrisi, R., \& Jaccard, J. (1992). Cognitive and attitudinal factors in the analysis of alternatives to drunk driving. Journal of Studies on Alcohol, 53, 405-414.

Voas, R. B., Torres, P., Romano, E., \& Lacey, J. H. (2012). Alcohol - related risk of driver fatalities: an update using 2007 data. Journal Studies of Alcohol and Drugs, 73, 341-350.

Watling, C. N., \& Freeman, J. (2011). Exploring the theoretical underpinnings of driving whilst influenced by illicit substances. Transportation Research Part F: Traffic Psychology and Behaviour, 14, 567-578.

Wontorczyk, A. (2011). Niebezpieczne zachowanie kierowców. Psychologiczny model regulacji zachowań w ruchu drogowym [Dangerous behaviors in drivers. Psychological model of the regulation of behaviors in the road traffic]. Cracow: Wydawnictwo Uniwersytetu Jagiellońskiego. 
Wytkowska, A. M. (2003). Temperament a poznawczo-behawioralny styl funkcjonowania jednostki [Temperament and cognitive-behavioral style of personal activity]. Acta Universitatis Lodziensis, Folia Psychologica, 7, 87-97.

Zador, P., Krawchuk, S., \& Voas, R. (2000). Alcohol-related relative risk of driver fatalities and driver involvement in fatal crashes in relation to driver age and gender. Journal of Studies on Alcohol, 61, 387-395.

Zawadzki, B., \& Strelau, J. (2010). Structure of personality: Search for a general factor viewed from a temperament perspective. Personality and Indyvidual Diffrences, 49, 77-82.

Zuckerman, M. (1994). Behavioral expressions and biosocial bases of sensation seeking. Cambridge: Cambridge University Press. 